\title{
PENGGUNAAN MEDIA KOMUNIKASI PROMOSI PARIWISATA OLEH PEMERINTAH KOTA MANADO
}

\author{
Elfie Mingkid \\ Jurusan Komunikasi, Fakultas Ilmu Sosial dan Politik. Universitas Sam Ratulangi Manado \\ elfie_mingkid@yahoo.com; 081356909022
}

\begin{abstract}
ABSTRAK. Kurangnya akses informasi yang menyangkut potensi pariwisata maupun kegiatan - kegiatan pemerintah kota dalam bidang pariwisata menunjukkan pada tidak difungsikannya media komunikasi dalam menunjang kegiatan yang berkaitan dengan promosi pariwisata. Penelitian ini diharapkan dapat menemukan penyebab belum difungsikannya dengan baik media komunikasi dalam promosi pariwisata oleh Dinas Pariwisata dan Kebudayaan Kota Manado serta menunjukkan pentingnya unsur media dalam tataran komunikasi khusunya pada kajian komunikasi organisasi publik. Dengan menggunakan desain deskriptif kualitatif ditemukan bahwa penggunaan media komunikasi yang dimiliki dalam kegiatan promosi kepariwisataan belum menjadikan promosi pariwiata berjalan dengan baik disebabkan oleh kurangnya dana untuk membiayai operasional, sistem jaringan sering bermasalah, belum adanya pegawai dalam struktur organisasi yang ditempatkan secara tetap memiliki keahlian di bidang teknologi informasi dan desain grafis, serta sarana dan prasarana kantor termasuk kompleks perkantoran yang belum memadai. Oleh karenanya Pemerintah Kota Manado perlu memanfaatkan website www. pariwisatakotamanado.go.id penyediaan infomasi kepariwisataan, promosi wisata, agenda - agenda pariwisata Kota Manado.
\end{abstract}

Kata Kunci : Media Komunikasi, Promosi, Pariwisata.

ABSTRACT. Lack of access to information concerning the potential for tourism and activities - activities of the city government in the field of tourism shows difungsikannya no communication media in supporting activities related to the promotion of tourism. This study is expected to find the cause has not been well difungsikannya communication media in the promotion of tourism by the Department of Tourism and Culture of the city of Manado and demonstrate the importance of media elements in the level of communication especially in communication studies public organizations. By using descriptive qualitative found that the use of communication media held in the promotion of tourism has not made the promotion pariwiata run properly due to lack of funds to finance the operations, network systems often problematic, the lack of employees in the organizational structure that is placed permanently with expertise in the field information technology and graphic design, as well as office facilities and infrastructure, including inadequate office complex. Manado City Government therefore needs to utilize the website www.pariwisatakotamanado.go.id provision of tourism information, tourism promotion, agenda - Manado City tourism agenda.

Keywords: Media Communications, Promotion, Tourism.

\section{PENDAHULUAN}

Sulawesi Utara telah ditetapkan sebagai satu dari lima daerah tujuan wisata yang paling menjanjikan di Indomesia dan satu dari 10 daerah yang memiliki objek-objek wisata yang cukup menarik untuk dikunjungi. Namun demikian dalam kenyataannya, Dinas Pariwisata Kota Manado belum melaksanakan tugas pokok dan fungsinya untuk memelihara bahkan mengembangkan kepariwisataan. Hal ini disebabkan kurangnya komunikasi yang menunjang kegiatan operasional di lapangan.

Buruknya komunikasi organisasi dalam meng-komunikasikan dan mempromosikan potensi pari-wisata Kota Manado mengakibatkan pelaku pariwisata mengalami kesulitan untuk mengakses layanan informasi seperti data potensi pariwisata daerah yang akurat maupun kegiatan-kegiatan pemerintah kota dalam bidang pariwisata yang tercermin dalam perencanaan program kegiatan maupun program kebijakan yang memudahkan pelaku pariwisata maupun masyarakat luas. Kenyataan ini memberikan akibat pada beberapa program pemerintah yang tidak berhasil yaitu program Manado Kota Pariwisata Dunia 2010, tidak adanya agenda-agenda kegiatan kepariwisataan Kota Manado, Bunaken yang tidak tertata dengan baik (banyak sampah berserakan) maupun adanya reklamasi pantai yang berakibat pada minimnya sarana wisata pantai di Kota Manado.

Dalam kaitannya dengan pencapaian hasil kerja Dinas Pariwisata Kota Manado permasalahan yang terjadi antara lain minimnya akses informasi yang menyangkut potensi pariwisata maupun kegiatan-kegiatan pemerintah kota dalam bidang pariwisata, pemerintah seringkali kurang memperhatikan atribut proses komunikasi yang menunjukkan dampak komunikasi seperti sektor media maupun akses informasi ke media, menyediakan data informasi tentang potensi pariwisata secara teratur dan transparan, baik menyangkut dengan rencana atau proyek kegiatan, informasi tentang perubahan kebijakan serta ketentuan lainnya dan disampaikan menggunakan jaringan media komunikasi yang memadai dan tepat, sehingga masyarakat mudah mengakses layanan data informasi tersebut.

Menjadi sangat penting untuk dilakukannya perbaikan dalam komunikasi organisasi, mengingat selain upaya perbaikan kinerja public merupakan suatu 
untutan yang harus dijalankan dalam penyelenggaraan pemerintahan guna pelayanan kepada masyarakat, juga mengingat Kota Manado yang saat ini menjadi daerah yang berkembang yang terlihat dari berbagai kegiatan baik dalam bentuk iven nasional maupun international menjadikan Kota Manado sebagai tempat pelaksanaan memerlukan penanganan yang resius dalam penataan potensi-potensi pariwisata dan kebudayaan.

Mengacu pada beberapa permasalahan tersebut, maka terlihat bahwa komunikasi organisasi pemerintah Kota Manado, selain belum berfungsi dengan baik juga kurang komunikatif pemerintah hal ini memberikan layanan informasi seperti data potensi pariwisata daerah yang akurat maupun kegiatan-kegiatan pemerintah kota dalam bidang pariwisata yang tercermin dalam perencanaan program kegiatan maupun program kebijakan yang memudahkan pelaku pariwisata maupun masyarakat luas sebagai akibat pada hasil kerja yang kurang baik.

Perbaikan pada komunikasi organisasi perlu ditelusuri dari unsur-unsur yang membentuk komunikasi organisasi tersebut. Permasalahan yang didasarkan pada minimnya akses informasi yang menyangkut potensi pariwisata maupun kegiatan-kegiatan pemerintah kota dalam bidang pariwisata menunjukkan pada tidak difungsikannya unsur media atau sarana komunikasi dalam menunjang kegiatan yang berkaitan dengan promosi pariwisata.

Metode komunikasi merupakan cara yang dipergunakan dalam mengadakan hubungan dengan orang lain baik di dalam maupun di luar organisasi yang dalam kategori komunikasi metode lisan dan tulisan. Secara konseptual, pemahaman akan media komunikasi dapat terlihat dari pemikiran Harold Laswell dalam Mingkid (2012) In which channel yaitu saluran atau media yang digunakan dalam proses komunikasi apakah langsung atau tatap muka dan sebagainya; Siagian (1997 :122) bahwa poses komunikasi setidaknya melibatkan: Saluran, ialah alat yang digunakan oleh komunikator untuk menyampaikan pesan; Onong $(1986 ; 6)$ unsurunsur komunikasi antara lain adalah media yaitu sarana atau saluran yang mendukung pesan bila komunikan jauh tempatnya atau banyak jumlahnya.

Saluran adalah media yang dilalui pesan, saluran berkaitan dengan segala sarana yang dipergunakan oleh komunikator untuk menyampaikan pesan yang ingin di sampaikan kepada pihak lain baik di dalam maupun di luar organisasi apakah menyangkut alat yang digunakan maupun melalui pengindrahan tubuh. Dengan memahami metode dan sarana, peneliti menganggap bahwa metode dalam komunikasi organisasi dapat dijelaskan dengan sarana yang digunakan dalam proses komunikasi.

Salah satu tantangan besar di dalam komunikasi organisasi adalah bagaimana menyampaikan informasi keseluruh bagian organisasi dan bagaimana menerima informasi dari seluruh bagian organisasi. Proses ini berhubungan dengan aliran informasi dimana dalam aliran informasi ada tiga cara yaitu serentak, berurutan dan kombinasi keduanya. Maka dalam hal itu sangat dibutuhkan suatu kerja sama yang baik, baik dengan pimpinan, dengan bawahan, maupun dengan sesama pegawai dalam hal pemberian perintah/laporan atau pun bermusyawarah. Suatu hubungan yang tercipta baik antara pimpinan dengan pegawai, dengan bawahan atau dengan sesama pegawai maupun dengan pelaku pariwisata seperti biro perjalanan wisata akan sangat mempengaruhi terwujudnya promosi pariwisata yang dapat meningkatkan kunjungan wisman di Kota Manado.

Memahami hal tersebut diatas, maka menjadi penting untuk dikaji menyangkut penggunaan media komunikasi dari Dinas Pariwisata dan Kebudayaan dalam mempromosikan potensi-potensi wisata serta agenda kepariwisataan di Kota Manado melalui kajian ilmiah. Melalui penelitian ini diharapkan dapat menemukan penyebab belum difungsikannya dengan baik media komunikasi dalam kaitan dengan penyebab dan kendalanya oleh pemerintah Kota Manado serta menunjukkan pentingnya unsure media dalam tataran komunikasi dalam pengembangan keilmuan khusunya pada kajian komunikasi organisasi publik.

\section{METODE PENELITIAN}

Tujuan utama penelitian ini tidak hanya sekedar untuk mendeskripsikan objek penelitian, namun mencakup proses pengekplorasian data dan fakta terhadap objek di lapangan sebagaimana apa adanya. Secara substansial media komunikasi pada pemerintah Kota Manado bukan hanya sekedar realitas sosial yang bersifat kontekstual. Oleh sebab itu, guna memberikan suatu pemahaman mengenai media komunikasi maka tafsiran-tafsiran kualitatif sangat diperlukan untuk memberikan keyakinan dan penggambaran secara integratif. Dengan demikian, metode penelitian yang dipandang sangat relevan dalam penelitian ini adalah metode kualitatif(Bungin, 2007). Sedangkan desain yang digunakan adalah deskriptif. Melalui desain deskriptif ini penulis dapat memberikan gambaran dan pemahaman serta mengungkapkan makna yang terkandung dalam obyek penelitian secara rinci, mendalam dan menyeluruh berdasarkan persepsi pelaku di lapangan.

Dalam penelitian kualitatif dengan menggunakan desain deskriptif, instrumen utama penelitian adalah peneliti sendiri. Data dikumpulkan melalui wawancara Kepala Bidang Pemasaran dan Promosi, Kepala Seksi Promosi dan Pelayanan Informasi dan Kepala Seksi Kalender Wisata sebagai informan dalam penelitian ini serta didukung dengan kegiatan observasi di lokasi penelitian dan menggunakan dokumen yang berkaitan dengan media komunikasi (Moloeng, 2001). Analisis data dalam penelitian ini dimulai dengan melaksanakan proses reduksi data, kemudian memilah-milahnya ke dalam kategori tertentu. Langka selanjutnya penulis membuat rangkuman secara diskriptif dan sistematis sehingga tema sentral yaitu media komunikasi pada Dinas Pariwisata dan Kebudayaan Kota Manado dapat dengan mudah diketahui. Selanjutnya penulis melakukan penarikan kesimpulan yang didasarkan pada data yang diperoleh dari berbagai sumber dan bersifat sementara sambil 
mencari data pendukung lainnya. Pada tahap ini penulis melakukan pengkajian tentang kesimpulan yang akan diambil dengan data pembanding dari teori tertentu (Cresswel, 1998). Hal itu penulis lakukan guna melihat kebenaran hasil analisis yang akan melahirkan kesimpulan yang dapat dipercaya.

\section{HASIL DAN PEMBAHASAN}

Media komunikasi merupakan sarana yang digunakan oleh komunkator dalam penyampaikan pesan keda komunikan baik secara lisan maupun tulisan. Penggunaan saluran komunikasi yang tepat menjadikan komunkasi efektif. Saluran komunkasi dengan mempergunakan alat bantu baik visual mauoun non visual (lisan maupun tulisan) memudahkan proses komunikasi dalam organisasi.

Saluran atau media komunikasi juga merupakan alat-alat atau sarana untuk membangkitkan motivasi komunikan dan mempermudah penyampaian informasi serta memperjelas isi dan maksud informasi yang akan disampaikan. Aktivitas pemerintah daerah dalam upaya penyampaian pesan kepada masyarakat, maka kemampuan menggunakan media sebagai penyalur pesan sangatlah penting. Hal itu karena media komunikasi memiliki kapasitas yang berbedabeda dalam menyampaikan informasi. Tujuan dari setiap kegiatan komunikasi yakni agar pesan-pesan atau informasi yang disampaikan dapat diterima dan dipahami oleh pihak yang dituju (komunikan). Agar maksud dari komunikasi yang dilakukan dapat dipahami dan diterima serta dilaksanakan untuk kepentingan bersama, maka dibutuhkan adanya saluran atau media komunikasi.

Melalui metode yang ada serta yang digunakan sebagiana terekam dalam data lapangan memperlihatkan melalui metode tatap muka langsung guna penyampaian ide, gagasan maupun perintah selalu di gunakan oleh Dinas pariwisata dan Kebudayaan Kota manado. Saluran atau media komunikasi itu berfungsi sebagai sarana penunjang guna terciptanya komunikasi yang lingkungan komunikatif, diantara komunikator dan komunikan dalam mempertukarkan dan merundingkan makna di antara semua pihak dan unsur dalam komunikasi (exchange and negotiation of meaning). Willard V sebagaimana dikutip oleh Yuwono (1985:3), "komunikasi adalah kegiatan mengajukan pengertian yang diinginkan dari pengirim informasi kepada penerima informasi dan menimbulkan tingkah laku yang diinginkan dari penerima informasi." Hal itu mengindikasikan bahwa komunikasi bukan sekedar upaya memberi tahu (informatif), tetapi juga persuasif yaitu berupaya mempengaruhi seseorang atau sejumlah orang untuk melakukan kegiatan atau tindakan tertentu, melalui berbagai saluran atau media yang ada. Oleh karena itu, komunikator dalam menyampaikan pesannya dapat memilih saluran komunikasi yang efisien untuk menyampaikan pesannya kepada komunikan. Saluran komunikasi merupakan media yang digunakan untuk membawa pesan kepada komunikan. Saluran komunikasi itu haruslah merupakan jaringan yang lingkungan komunikatif, dimana pesan yang dialirkan dapat menghubungkan komunikator dengan komunikan untuk berkomunikasi.

Penggunaan saluran komunikasi juga dapat dipahami lebih lanjut dengan memperhatikan data lapangan melalui media surat, sementara penggunaan Teknologi Komunikasi (IT) masih kurang dimanfaatkan oleh Dinas Pariwisata dan Kebudayaan Kota Manado. Dalam konteks tersebut di atas, saluran komunikasi dapat dipahami sebagai arus informasi karena begitu eratnya hubungan antara pelayanan dengan hal-hal yang akan dicapai. Pelayanan informasi yang dilakukan oleh Dinas Pariwisata dan Kebudayaan Kota Mamado merupakan suatu bentuk fungsi Pemerintah Kota Manado dalam memberikan pelayanan khususnya pelayanan pariwisata dan kebudayaan. Dalam upaya meningkatkan komunikasi dalam pelayanan promosi pariwisata agar mudah diketahui dan mudah diakses oleh pihak-pihak yang berkepentingan (publik) maka penggunaan media atau saluran komunikasi baik media cetak ataupun media elektronik dan visual merupakan alat bantu teknologi yang memberikan kemudahan bagi publik dalam menerima atau memperoleh informasi-informasi yang dibutuhkan terkait dengan promosi pariwisata.

Pemerintah Kota Manado melalui Dinas Pariwisata dan Kebudayaan dalam menjalin hubungan komunikasi publik untuk mempromosikan kalender pariwisata dan proposi pariwisata Kota Manado lebih banyak menggunakan sarana komunikasi seperti telepon, faximile, koran, majalah dan radio serta televisi. Sekalipun memang pemanfaatan teknologi informasi dalam pemasaran pariwisata pada tahun 2011 ditargetkan untuk membangun website pariwisata dan kebudayaan dan peningkatan sarana perangkat teknologi informasi terelisasi melalui pelaksanaan kegiatan peningkatan dan pemanfaatan teknologi informasi dalam pemasaran pariwisata, berupa pengembangan Website Dinas Pariwisata dan Kebudayaan Kota Manado padasitus resmi: www.pariwisatakotamanado.go.id dan peningkatan sarana perangkat teknologi informasi yaitu pengadaan 2 unit komputer server internet dan pemanfaatan anjungan multimedia touchscreen yang ditempatkan di Pusat Informasi Pariwisata Taman Kesatuan Bangsa sehingga memudahkan akses masyarakat untuk memperoleh informasi kepariwisataan. Akan tetapi penggunaan www.pariwisatakotamanado.go.id masih sebatas pada publikasi produk-produk hukum berupa undang-undang, peraturan dan kebijakan-kebijakan terbaru dari pemerintah pusat maupun informasi berita perkembangan lainnya yang berhubungan dengan tugas pokok dan fungsi serta sumber daya manusia Dinas Pariwisata dan Kebudayaan.

Dari penelitian yang dilakukan ditemukan bahwa berbagai kendala yang dihadapi oleh Dinas Pariwisata dan Kebudayaan dan Kebudayaan Kota Manado yang dimiliki dalam meningkatkan akses informasi dan ketersediaan bahan promosi yang dapat diakses wisatawan secara mudah dan dengan informasi akurat dalam mempromosikan pariwisata berkaitan dengan kurangnya dana untuk membiayai operasional, sistem jaringan sering bermasalah, belum adanya 
pegawai dalam struktur organisasi yang ditempatkan secara tetap memiliki keahlian di bidang teknologi informasi dan desain grafis, serta sarana dan prasarana kantor termasuk kompleks perkantoran yang belum memadai.

Upaya mengimbangi kecepatan teknologi Pemerintah Kota Manado melalui $\underline{w w w}$. pariwisatakotamanado.go.id dalam pengoperasiannya belum maksimal karena masih terdapat bagian-bagian informasi yang belum banyak mengalami perubahan. Pemanfaatan saluran komunikasi ini terkesan belum dapat memberikan akses percepatan dalam memperoleh informasi tentang promosi pariwisata karena lebih banyak memuat hal - hal yang berhubungan dengan aturan, kebijakan, visi dan misi dinas maupun keberadaan Pemerintahan Kota Manado.

Peran saluran komunikasi adalah untuk menyalurkan informasi. Saluran komunikasi dibutuhkan pada setiap aktivitas pemerintah daerah, karena terkait dengan salah satu fungsi pemerintah yakni memberikan layanan informasi. Dewasa ini kecanggihan teknologi informasi dan komunikasi telah melahirkan banyak saluran-saluran atau jaringan media yang pada dijadikan sebagai pilihan bagi organisasi untuk penyampaian pesannya kepada publik. Pemanfaatan saluran media penting karena mampu menjangkau seluruh lapisan masyarakat seperti melalui internet yang merupakan media yang penyajian informasi berlangsung secara online.

Era globalisasi yang ditandai dengan berkembangnya pemanfaatan teknologi komunikasi dan komputer tersebut, turut mempengaruhi penyelenggaraan pemerintahan di Indonesia. Pemerintah saat ini mulai memanfaatkan teknologi komputer sejalan dengan perkembangan jaman. Pemanfaatan teknologi komputer ini diharapkan dapatmenciptakan pemerintahanyang lebih baik (good governance). Good governance merupakan perangkat untuk menciptakan penyelenggaraan negara yang solid, bertanggung jawab, efektif dan efisien, dengan menjaga keserasian interaksi yang konstruktif di antara domain negara, sektor swasta dan masyarakat.

Teknologi, Informasi dan Komunikasi (TIK) merupakan salah satu solusi untuk memperbaiki birokrasi dalam rangka menciptakan pemerintahan yang lebih baik. Tetapi yang terpenting adalah untuk memberikan pelayanan yang prima antar pemerintah dan dari pemerintah untuk masyarakat. TIK menawarkan peluang kepada pemerintah untuk memberikan layanan dan berinteraksi yang lebih baik kepada semua konstituen; masyarakat, kalangan bisnis, dan mitra pemerintah lainnya. Undang-Undang Republik Indonesia Nomor 11 Tahun 2008 dan Instruksi Presiden Nomor 3 Tahun 2003 merupakan bentuk pengaturan pengelolaan informasi dan transaksi elektronik di tingkat nasional sehingga pembangunan Teknologi Informasi (TI) dapat dilakukan secara optimal, merata, dan menyebar keseluruh lapisan masyarakat guna mencerdaskan kehidupan bangsa. Pemanfaatan TI ini dilakukan secara aman untuk mencegah penyalahgunaannya dengan tetap memperhatikan nilai-nilai agama dan sosial budaya masyarakat Indonesia.
Penyelenggaraan pemerintahan saat inimengenal adanya e-Government yang didefinisikan sebagai sebuah aplikasi teknologi informasi dan komunikasi oleh kantor pemerintah. Kemampuan pemerintah sebagai organisasi kekuasaan seharusnya dapat menerapkan berbagai hal, termasuk di dalam penerapan e-Government yang menyediakan layanan dalam bentuk elektronik. Pelayanan yang diberikan pemerintah secara online akan memudahkan warga negara untuk ikut berpartisipasi dalam berbagai penyelenggaraan pemerintahan. Selain itu, pelayanan yang diberikan secara online juga bermanfaat untuk mengurangi biaya, proses yang berbelit-belit, menambah kecepatan, serta membuat proses lebih fleksibel dan responsif.

Promosi pariwisata unsur penting dalam pencapaian kinerja pariwisata. Tanggung jawab utama yang diperang oleh pemerintah adalah bagaimana program pariwisata yang telah ditetapkan dapat diketahui oleh masyarakat umum. Peranan pemerintah dalam promosi pariwisata ini juga sangat penting. Peran pemerintah daerah diperlukan untuk tugas pemasaran dan promosi Kota Manado secara umum sebagai tujuan pariwisata terutama bagi para wisatawan mancanegara, melalui penciptaan 'brand image' yang kuat. Dalam kapasitasnya untuk mempromosikan potensi wisata untuk dapat diketahui oleh masyarakat luas termasuk yang berada di luar Manado dan bahkan sampai ke luar negara, promosi pariwisata yang disajikan melaui website menjadi sangat penting digunakan.

Memperhatikan rencana pemasaran dan promosi pariwisata Kota Manado yang ditetapkan oleh Pemerintah Kota Manado melalui Dinas Pariwisata dan Kebudayan yaitu mengembangkan image pariwisata Kota Manado sebagai marine dan water sport tourism dengan Taman Nasional Bunaken sebagai obyek wisata andalan, serta MICE and shoping tourism dengan kawasan waterfront dan Boulevard Manado sebagai daya tarik utamanya, memperluas outlet informasi dan pemasaran pariwisata Kota Manado di lokasilokasi strategis (bandara, pelabuhan, pusat kota), mengembangkan paket wisata terpadu antar obyek wisata yang ada di Kota Manado khususnya dan obyekobyek wisata lain di kota-kota sekitarnya melalui kerjasama antar Dinas Pariwisata, tour operator, travel agency, dan stakeholders terkait lainnya. Akan tetapi menjadi tidak kalah penting juga adalah meningkatkan akses informasi dan ketersediaan bahan promosi yang dapat diakses wisatawan secara mudah dan dengan informasi akurat melalui pemanfaatan media komuniasi yang tepat dan benar.

Mengingat informasi yang cepat berubah dan lingkungan komunikasi yang berbeda, maka penguatan kapasitas organisasi dalam menyampaikan informasi kepada masyarakat dapat menggunakan campuran media dan teknologi. Dengan menggunakan informasi baru dan teknologi komunikasi dapat membantu pemerintah meningkatkan promosi kepariwisataan. Proses transformasi dengan menggunakan informasi baru dan teknologi komunikas sebagai media komunikasi menjadikan pemerintah dapat mengoptimalisasikan 
pemanfaatan teknologi informasi untuk mengeliminasi sekat-sekat organisasi birokrasi serta membentuk jaringan sistem manajemen dan proses kerja yang memungkinkan pemerintah, swasta dan masyarakat bekerja secara terpadu mempromosikan potensi pariwisata kepada masyarakat umum.

\section{SIMPULAN}

Berdasarkan hasil penelitian yang ada, menunjukkan bahwa penggunaan media komunikasi yang saat ini dimiliki oleh Dinas Pariwisata dan Kebudayaan Kota Manado dalam kegiatan promosi kepariwisataan belum dapat menjadikan promosi pariwiata berjalan dengan baik disebabkan oleh kurangnya dana untuk membiayai operasional, sistem jaringan sering bermasalah, belum adanya pegawai dalam struktur organisasi yang ditempatkan secara tetap memiliki keahlian di bidang teknologi informasi dan desain grafis, serta sarana dan prasarana kantor termasuk kompleks perkantoran yang belum memadai. Sehingga informasi yang disampaikan berkaitan dengan promosi kepariwisataan dan agenda agenda pariwisata Kota Manado belum secara maksimal di publikasikan dalam media tersebut dan belum dapat diterima dengan baik oleh wisatawan local dan manca negara.

Media komunikasi seperti telepon, faximile, koran, majalah dan radio serta televisi yang digunakan dalam kegiatan promosi pariwisata tidak dapat menjangkau target pasar pariwisata Kota Manado. Sementara penggunaan situs www.pariwisatakotamanado.go.id belum menjadikan promosi pariwisata menjadi lebih baik karena selain belum dapat dengam mudah diakses oleh masyarakat luas juga isi pesan yang ada di situs lebih banyak memuat peraturan dan kebijakan-kebijakan pemerintah yang berkaitan dengan Dinas Pariwisata dan Kebudayaan Kota Manado.
Oleh karenanya guna meningkatkan promosi pariwisata, maka Pemerintah Kota Manado perlu untuk melakukan perbaikan pada penggunaan media komunikasi dengan lebih memanfaatkan situs website www.pariwisatakotamanado.go.id melalui penyediaan infomasi kepariwisataan, promosi wisata, agendaagenda pariwisata, melakukan pembenahan pada sumber daya manusia, dana peralatan. Selain itu pula perlu memaksimalkan hubungan kerja dengan pelaku pariwisata lainnya seperti pihak biro perjalanan wisata, hotel, trevel dalam memfungsikan media situs website guna promosi pariwisata di Kota Manado.

\section{DAFTAR PUSTAKA}

Bungin, B. 2007. Penelitian Kualitatf; Komunikasi, Ekonomi, Kebijakan Publik dan Ilmu Sosial Lainnya, Jakarta: Kencana.

Cresswel, J.W. 1998. Qualitative Inquiry and Research Design: Choosing Among Five Traditions. California:SAGE Publications, Inc.

Instruksi Presiden Nomor 3 Tahun 2003 tentang Panduan Kebijakan Strategi Nasional Elektronik Government

Moloeng, L.J. 2001, Metode Penelitian Kualitatif, Bandung : Remaja Rosdakarya.

Siagian, S.P. 1997. Organisasi, Kepemimpinan dan Perilaku Administrasi. Jakarta : Gunung Agung.

Onong, U.E. 1986, Dinamika Komunikasi, Bandung : Remajakarya

Robbins, S. 2001. Perilaku Organisasi, Konsep, Kontroversi, Aplikasi, Jakarta : Prenhallindo.

Undang-Undang Republik Indonesia Nomor 11 Tahun 2008 tentang Informasi dan Transaksi Elektronik.

Yuwono, S. 1985. Ikhtisar Komunikasi Administrasi. Yogyakarta: Liberty. 